THE SCHOLEMS 



\title{
THE SCHOLEMS
}

\author{
A Story of the German-Jewish \\ Bourgeoisie from Emancipation \\ to Destruction
}

JAY HOWARD GELLER 
Copyright (C) 2019 by Cornell University

All rights reserved. Except for brief quotations in a review, this book, or parts thereof, must not be reproduced in any form without permission in writing from the publisher. For information, address Cornell University Press, Sage House, 512 East State Street, Ithaca, New York 14850. Visit our website at cornellpress.cornell.edu.

First published 2019 by Cornell University Press

Printed in the United States of America

Library of Congress Cataloging-in-Publication Data

Names: Geller, Jay Howard, author.

Title: The Scholems : a story of the German-Jewish bourgeoisie from emancipation to destruction / Jay Howard Geller.

Description: Ithaca : Cornell University Press, 2019. Includes bibliographical references and index.

Identifiers: LCCN 2018029901 (print) | LCCN 2018033456 (ebook) | ISBN 9781501731570 (pdf) | ISBN 9781501731587 (epub/mobi) | ISBN 9781501731563 | ISBN 9781501731563 (cloth ; alk. paper)

Subjects: LCSH: Scholem, Gershom, 1897-1982. | Scholem, Gershom, 1897-1982-Family. | Jewish scholars-Germany-Biography. | Jews-GermanyBiography. | Jews-Germany-History-20th century. | Middle class-Germany-History—20th century.

Classification: LCC BM755.S295 (ebook) | LCC BM755. S295 G45 2018 (print) | DDC 305.892/ 40430922 [B]- dc23

LC record available at https: / /ccn.loc.gov/2018029901

Cover images:

Top: The Scholem family, courtesy of the National Library of Israel, ARC. $4^{\star} 1599 / 10 / 08,003800443$

Bottom: The Brandenburg Gate in Berlin, courtesy of the Library of Congress, LOT 14184, no. 257 (P\&P) 